\title{
Nitrogen, Phosphorus, and Potassium Requirements for Optimizing Growth and Flowering of the Nobile Dendrobium as a Potted Orchid
}

\author{
Rebecca G. Bichsel ${ }^{1}$ and Terri W. Starman ${ }^{2,4}$ \\ Department of Horticultural Sciences, 2133 TAMU, Texas A\&M University, \\ College Station, TX 77843
}

Yin-Tung Wang ${ }^{3}$

Department of Horticultural Sciences, Texas A\&M University System, Texas Agricultural Research and Extension Center, 2415 East Highway 83, Weslaco, TX 78596

\section{Additional index words. Dendrobium nobile, mineral nutrition}

\begin{abstract}
Experiments were conducted to determine how nitrogen $(\mathrm{N})$, phosphorus $(\mathrm{P})$, and potassium $(\mathrm{K})$ rate and fertilizer termination time affect the growth and flowering of a Dendrobium nobile Lindl. hybrid, Dendrobium cv Red Emperor 'Prince'. Nitrogen, P, and $K$ were tested in separate experiments as a factorial combination of five rates and three termination dates (1 Sept., 1 Oct., and 1 Nov. 2005). Nitrogen and $K$ rates were 0 , $50,100,200$, and $400 \mathrm{mg} \cdot \mathrm{L}^{-1}$. Phosphorus rates were $0,25,50,100$, and $200 \mathrm{mg} \cdot \mathrm{L}^{-1}$. Levels of the nutrients not being tested were held constant. For all nutrients, ending fertilization on 1 Sept. resulted in greater or similar pseudobulb thickness compared with ending fertilization on 1 Oct. or 1 Nov. Pseudobulbs grew taller as the $\mathbf{N}$ rate increased, peaking at 100 and $200 \mathrm{mg} \cdot \mathrm{L}^{-1}$. There were interactions between the $\mathrm{N}$ rate and fertilizer termination time on all reproductive characteristics. For all fertilizer termination times, flower number increased once $N$ was applied. When ended on $1 \mathrm{Nov} ., 200$ and $400 \mathrm{mg} \cdot \mathrm{L}^{-1}$ $\mathrm{N}$ caused a delay to reach anthesis. All $\mathrm{P}$ rates resulted in taller plants with equally more nodes when compared with $0 \mathrm{mg} \cdot \mathrm{L}^{-1}$. As the $\mathrm{K}$ rate increased from 0 to $100 \mathrm{mg} \cdot \mathrm{L}^{-1}$, plant height increased, with no further increase at higher rates. The number of leaves remaining increased as $\mathrm{N}$ and $\mathrm{K}$ rates increased up to $200 \mathrm{mg} \cdot \mathrm{L}^{-1}$. Total flower number and flowering node number increased as the $\mathrm{K}$ rate increased to $100 \mathrm{mg} \cdot \mathrm{L}^{-1}$ (terminated on 1 Sept.) or $50 \mathrm{mg} \cdot \mathrm{L}^{-1}$ (terminated on 1 Oct. or 1 Nov.). In the fourth experiment, only $\mathbf{N}$ was ended at four termination times, whereas all other nutrients continued to be supplied until flowering. Control plants received all fertilizer elements until flowering. The duration of $\mathbf{N}$ application did not affect vegetative or flowering characteristics. No aerial shoots were observed as a result of prolonged application of $\mathbf{N}$ at all rates. In summary, $100 \mathrm{mg} \cdot \mathrm{L}^{-1} \mathrm{~N}, 25 \mathrm{mg} \cdot \mathrm{L}^{-1} \mathrm{P}$, and $100 \mathrm{mg} \cdot \mathrm{L}^{-1} \mathrm{~K}$ are recommended for optimal vegetative growth and reproductive development of Dendrobium cv Red Emperor 'Prince'.
\end{abstract}

The production of potted orchids has increased since the early 1990 s because of advances in propagation and cultivation techniques and consumer demand. Orchids are recognized as a profitable crop by commercial growers (Britt, 2000). In 2006, the USDA estimated the wholesale value of orchids in the United States to be $\$ 144$ million (USDA, 2006), with Phalaenopsis Blume constituting the majority of production.

Received for publication 29 June 2007. Accepted for publication 15 Oct. 2007.

We thank Yamamoto Dendroblum (Hawaii) for providing the plants used in this study.

${ }^{1}$ Former Graduate Research Assistant.

${ }^{2}$ Associate Professor.

${ }^{3}$ Professor. Current address: Matsui Nursery, 1645 Old Stage Road, Salinas, CA 93908. E-mail yintung.wang@gmail.com.

${ }^{4}$ To whom reprint requests should be addressed; e-mail tstarman@tamu.edu
Although Phalaenopsis remains the most popular potted orchid sold, the types of orchids on the market are becoming more diversified. Potted hybrid Dendrobium Sw. plants are being cultivated at an ever-increasing rate. The species Dendrobium nobile Lindley (the nobile dendrobium) is native to Burma, India, Indochina, and Thailand (Baker and Baker, 1996), and is one of the most frequently cultivated because of its potential to flower abundantly when grown under favorable conditions. Hybrids made from $D$. nobile have the potential to become very popular in the flowering potted plant market because, as tastes of the consumer change, the demand for other types of orchids emerges.

In the past, most orchid production research in the United States focused on Phalaenopsis to help growers produce them more efficiently (Wang, 1996; Wang, 2000; Wang and Konow, 2002). In contrast to Phalaenopsis, information about the produc- tion requirements for hybrid nobile dendrobium remains largely unknown. One study found that when grown in Sphagnum magellanicum Brid. or hemlock (Conium maculatum L.) bark, pseudobulb number, length, and width, as well as leaf number, were all highest at $1000 \mathrm{mg} \cdot \mathrm{L}^{-1} \mathrm{~N}$ (Miwa and Ozaki, 1975). However, plants that received $1000 \mathrm{mg} \cdot \mathrm{L}^{-1} \mathrm{~N}$ produced the least flowering nodes and resulted in the greatest number of aerial shoots. This $\mathrm{N}$ rate seems unrealistically high and could have caused root injury (Wang, 1998). Lack of $\mathrm{P}$ resulted in decreased pseudobulb number, length and width, and leaf number. Flowering node number and number of flowers per node decreased and flowering was delayed when no $\mathrm{P}$ was applied. Potassium at any level, including $0 \mathrm{mg} \cdot \mathrm{L}^{-1}$, was shown to have no effects on plants (Miwa and Ozaki, 1975). The requirements for mineral nutrients, particularly $\mathrm{N}, \mathrm{P}$, and $\mathrm{K}$, temperature, and light of the more modern nobile dendrobium cultivars require investigation. The nutrient termination time is important in this species to produce a flower rather than an aerial shoot from a pseudobulb node (Yamamoto Dendrobiums, 2006).

The objective of this study was to determine how various rates of $\mathrm{N}, \mathrm{P}$, and $\mathrm{K}$ and nutrient termination times would affect the growth and flowering of Dendrobium cv Red Emperor 'Prince'.

\section{Materials and Methods}

One-year-old Dendrobium cv Red Emperor 'Prince' liners, each having a single pseudobulb, were received from Yamamoto Dendrobiums (Mountain View, HI) on 3 Feb. 2005. The young plants were propagated from single-node stem cuttings in 72-cell plug trays filled with sphagnum moss as the root substrate. After arrival, plants were potted singly in 10.2-cm (top diameter, 414 $\mathrm{mL}$ vol.) standard round green plastic pots on 4 Feb. 2005 in a root substrate consisting of 2 coarse sphagnum peat: 1 perlite (no. 3):1 diatomite (no. $3 ; 90 \%$ silicon dioxide, $10 \%$ elemental minerals; Diatomite USA, Elma, $\mathrm{NY}$; by volume) with $0.5 \mathrm{~g} \cdot \mathrm{L}^{-1}$ Micromax (a micronutrient source; The Scotts Company, Marysville, $\mathrm{OH}$ ), and $5.0 \mathrm{~g} \cdot \mathrm{L}^{-1}$ powdered dolomite.

Immediately after potting, plants were watered with reverse osmosis (RO) water containing a fungicide (Banrot $40 \% \mathrm{WP}$; Scotts-Sierra Crop Protection Company, Marysville, $\mathrm{OH}$ ) at a rate of $59.8 \mathrm{mg} \cdot \mathrm{L}^{-1}$ to prevent root rot. Plants continued to be watered with RO water until 22 Feb. 2005 when treatments commenced.

Three experiments were conducted simultaneously because of availability of plant materials. Each of the N, P, and K experiments was a factorial treatment combination of five $\mathrm{N}, \mathrm{P}$, or $\mathrm{K}$ rates and three fertilizer termination times. The five rates for $\mathrm{N}$ and $\mathrm{K}$ were $0,50,100,200$, and $400 \mathrm{mg} \cdot \mathrm{L}^{-1}$ and for $\mathrm{P}$ were $0,25,50,100$, and $200 \mathrm{mg} \cdot \mathrm{L}^{-1}$. In $0 \mathrm{mg} \cdot \mathrm{L}^{-1}$ rates, only the nutrient being tested 
was eliminated. Each experiment was designed to allow for only $\mathrm{N}, \mathrm{P}$, or $\mathrm{K}$ rate to change while all other nutrient rates were held constant (Table 1). N stayed constant at $100 \mathrm{mg} \cdot \mathrm{L}^{-1}$ in the $\mathrm{P}$ and $\mathrm{K}$ experiments. $\mathrm{P}$ was held constant at $200 \mathrm{mg} \cdot \mathrm{L}^{-1}$ in the $\mathrm{N}$ experiments and at $250 \mathrm{mg} \cdot \mathrm{L}^{-1}$ in the $\mathrm{K}$ experiments. $\mathrm{K}$ was kept constant at $250 \mathrm{mg} \cdot \mathrm{L}^{-1}$ in the $\mathrm{N}$ and $\mathrm{P}$ experiments. Analytical grade $\mathrm{CaCl}_{2} \cdot \mathrm{H}_{2} \mathrm{O}, \mathrm{KH}_{2} \mathrm{PO}_{4}, \mathrm{KNO}_{3}, \mathrm{MgSO}_{4} \cdot 7 \mathrm{H}_{2} \mathrm{O}$, $\mathrm{NH}_{4} \mathrm{NO}_{3}$, and $\mathrm{NH}_{4} \mathrm{H}_{2} \mathrm{PO}_{4}$ were used to add nutrients to the fertilizer solution.

The three fertilizer termination times for all experiments were 1 Sept. [FT-1, 209 d after planting (DAP)], 1 Oct. (FT-2, 239 DAP), and 1 Nov. (FT-3, 270 DAP) 2005. At each fertilizer termination time, fertilizer application was ended and plants received only plain water when watering was needed.

A single plant represented an experimental unit and each treatment was replicated 10 times in a randomized complete block design within each experiment. There were 150 plants in each experiment.

At the beginning of the experiment, 15 pots were placed in each $29.5 \times 50.5-\mathrm{cm}$ molded carrying tray (4.00 AZ Transport Tray; Landmark Plastic Corporation, Akron, $\mathrm{OH}$ ), spaced $7.6 \mathrm{~cm}$ apart to simulate commercial growing conditions. To prevent lodging, plants were supported in July 2005 with bamboo stakes (Bamboo Stake Co., Lakeland, FL) cut at $30.5 \mathrm{~cm}$. On 6 Aug. 2005, plants from the middle row of the carrying trays were removed and placed in additional trays to improve spacing and air circulation. In mid-December 2005, to prepare for flowering, each of the $10.2-\mathrm{cm}$ pots was placed inside a $14.6-\mathrm{cm}(1.77 \mathrm{~L})$ pot surrounded by pea gravel and was given additional support with longer bamboo stakes. Pots were spaced at $232 \mathrm{~cm}^{2} /$ pot.

For all experiments, pots were watered by hand as needed when the medium was dry, and the surface was light in color by applying $100 \mathrm{~mL} /$ pot of the designated nutrient solution with $50 \%$ leaching fraction. As plants grew, $150 \mathrm{~mL}$ with $50 \%$ leaching fraction of the nutrient solution was applied per pot. After the termination of fertilization, plants

Table 1. The amount of chemicals used in $\mathrm{g} \cdot \mathrm{L}^{-1}$ to prepare nutrient solutions of various $\mathrm{N}, \mathrm{P}$, and $\mathrm{K}$ concentrations.

\begin{tabular}{lccccc}
\hline Experiment & Concn $\left(\mathrm{mg} \cdot \mathrm{L}^{-1}\right)$ & $\mathrm{KH}_{2} \mathrm{PO}_{4}$ & $\mathrm{KNO}_{3}$ & $\mathrm{NH}_{4} \mathrm{NO}_{3}$ & $\mathrm{NH}_{4} \mathrm{H}_{2} \mathrm{PO}_{4}$ \\
\hline (N) & & & & & \\
& 0 & 8.42 & 0 & 0 & 0 \\
& 50 & 8.42 & 0 & 1.37 & 0 \\
& 100 & 8.42 & 0 & 2.75 & 0 \\
& 200 & 8.42 & 0 & 5.48 & 0 \\
$(\mathrm{P})$ & 8.42 & 0 & 10.97 & 0 \\
& & & & & \\
& 0 & 1.06 & 5.20 & 0.30 & 0 \\
& 25 & 2.11 & 4.64 & 0.60 & 0 \\
& 50 & 8.21 & 3.07 & 1.54 & 0 \\
& 100 & & 0 & 2.75 & 0 \\
& 200 & 0 & 0 & 0.34 & 7.12 \\
& & 1.67 & 0 & 0.77 & 5.70 \\
& 0 & 3.35 & 0 & 1.26 & 4.27 \\
& 50 & 6.69 & 0 & 2.24 & 1.46 \\
& 100 & 6.69 & 4.97 & 0 & 1.46 \\
\hline
\end{tabular}

were watered with plain RO water by a handheld hose. Insecticides [Azadirachtin (Azatin) and Cyfluthrin (Decathlon); Olympic Horticulture Products, Mainland, PA] and a fungicide [Iprodione (Chipco); Bayer Environmental Science, Montvale, NJ] were applied at recommended rates as needed throughout the growing period.

Plants were grown in a greenhouse at lat. $30^{\circ} 37^{\prime} 40^{\prime \prime} \mathrm{N}$ and long. $96^{\circ} 20^{\prime} 3^{\prime \prime} \mathrm{E}$ with glass sides and a polycarbonate roof until the time of full flower. From February to Dec. 2005, temperature set points in the greenhouse were $24^{\circ} \mathrm{C}$ day $/ 18^{\circ} \mathrm{C}$ night. From February to Apr. 2005 , when two new shoots emerged from the base of an old pseudobulb, the second emerging shoot was removed to maintain one shoot per plant. From March to May, flower buds that formed on some of the old pseudobulbs were removed as needed to keep plants vegetative. Starting 15 Dec. 2005, temperature set points were dropped to $18{ }^{\circ} \mathrm{C}$ day/15 ${ }^{\circ} \mathrm{C}$ night to promote flower initiation. On 17 Jan. 2006 after flower initiation, temperature set points in the greenhouse were raised to 22 ${ }^{\circ} \mathrm{C}$ day $/ 17^{\circ} \mathrm{C}$ night to promote flowering. Data loggers (HOBO H8; Onset Computer Corp., Bourne, ME) were used to measure and record the actual greenhouse temperature. Greenhouse light levels were monitored at plant canopy level using line quantum sensors (LQS 50-3; Apogee Instruments, Logan, UT). Average monthly temperature ranged from a daytime high of $28^{\circ} \mathrm{C}$ in August to a nighttime low of $14{ }^{\circ} \mathrm{C}$ in December (Fig. 1), and the maximum daily light integral ranged from a high of $7.5 \mathrm{~mol} \cdot \mathrm{m}^{-2} \cdot \mathrm{d}^{-1}$ in July to a low of 4.2 $\mathrm{mol} \cdot \mathrm{m}^{-2} \cdot \mathrm{d}^{-1}$ in December (Fig. 1).

Data on plant height, pseudobulb (stem) node number, pseudobulb width and thickness, and number of leaves remaining were taken in December after all pseudobulbs had matured. Pseudobulb maturation was defined as the time when the uppermost leaf had fully expanded, the pseudobulb had fully swollen, and the top of the pseudobulb became rounded. Height was measured from the base to the top of the pseudobulb. Pseudobulb width and thickness measurements were taken with a digital caliper (Model 06-664- 


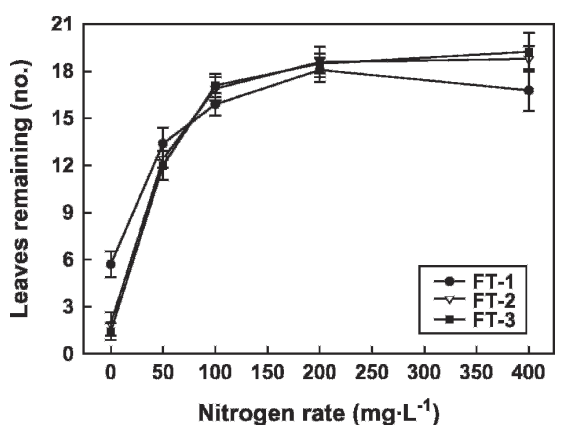

Fig. 2. Effect of nitrogen rate and fertilizer termination time on the number of leaves remaining counted at pseudobulb maturity for Dendrobium cv Red Emperor 'Prince'. FT-1 = first fertilizer termination time, 1 Sept. 2005. FT-2 = second fertilizer termination time, 1 Oct. 2005. FT-3 $=$ third fertilizer termination time, $1 \mathrm{Nov}$. 2005 . Bars indicate \pm SE of the mean.

number of leaves remaining at each of the $\mathrm{N}$ rates from 50 to $400 \mathrm{mg} \cdot \mathrm{L}^{-1}$ regardless of $\mathrm{N}$ termination times (Fig. 2). Fertilizer termination time had no effect on node number (data not shown).

For all termination times, plants became taller and had more nodes as the $\mathrm{N}$ rate increased from 0 to $50 \mathrm{mg} \cdot \mathrm{L}^{-1}$ (Table 2), reaching a peak at 100 and $200 \mathrm{mg} \cdot \mathrm{L}^{-1} \mathrm{~N}$, and were shorter when $\mathrm{N}$ increased to $400 \mathrm{mg} \cdot \mathrm{L}^{-1}$. Nitrogen rates did not result in any difference in pseudobulb width or thickness, except at $400 \mathrm{mg} \cdot \mathrm{L}^{-1} \mathrm{~N}$, which resulted in smaller pseudobulb width and thickness. Pseudobulbs were wider (data not shown) and thicker when fertilization was ended at FT-1 compared with FT-2 and FT-3, with no differences between the latter two (Fig. 3A).

As the $\mathrm{N}$ rate increased from 0 to 50 $\mathrm{mg} \cdot \mathrm{L}^{-1}$, total flower number increased for all fertilizer termination times and continued to increase for FT-2 to $100 \mathrm{mg} \cdot \mathrm{L}^{-1} \mathrm{~N}$ (Figs. 4A and 5A). When fertilization was ended at FT1 and FT-2, plants given $200 \mathrm{mg} \cdot \mathrm{L}^{1} \mathrm{~N}$ had flower numbers similar to that at $100 \mathrm{mg} \cdot \mathrm{L}^{-1}$ $\mathrm{N}$. When fertilization was ended at FT-3, total flower number decreased from 21 flowers at $200 \mathrm{mg} \cdot \mathrm{L}^{-1} \mathrm{~N}$ to 12 flowers at $400 \mathrm{mg} \cdot \mathrm{L}^{-1} \mathrm{~N}$.

At $0 \mathrm{mg} \cdot \mathrm{L}^{-1} \mathrm{~N}, \mathrm{FT}-1$ plants had larger flowers $(6 \mathrm{~cm})$ than those when $\mathrm{N}$ was ended at FT-2 or FT-3 $(5 \mathrm{~cm})$. Nitrogen rates from 50 to $200 \mathrm{mg} \cdot \mathrm{L}^{-1}$ resulted in plants with similar flower diameter $(7 \mathrm{~cm})$ for all fertilizer termination times.

Regardless of $\mathrm{N}$ rate, days to anthesis were similar for both FT-1 and FT-2 fertilizer

Table 2. Effect of the $\mathrm{N}$ rate regardless of fertilizer termination time on vegetative parameters measured at pseudobulb maturity for Dendrobium cv Red Emperor 'Prince'.

\begin{tabular}{ccccc}
\hline & $\begin{array}{c}\text { Plant height } \\
\text { N rate }\left(\mathrm{mg} \cdot \mathrm{L}^{-1}\right)\end{array}$ & Node no. & Width $(\mathrm{mm})$ & Thickness $(\mathrm{mm})$ \\
\cline { 3 - 5 } & $36.1 \mathrm{c}^{\mathrm{z}}$ & $11.8 \mathrm{~d}$ & $26.5 \mathrm{a}$ & $20.6 \mathrm{a}$ \\
50 & $56.2 \mathrm{~b}$ & $18.7 \mathrm{c}$ & $26.1 \mathrm{a}$ & $20.4 \mathrm{a}$ \\
100 & $64.1 \mathrm{a}$ & $21.8 \mathrm{a}$ & $26.2 \mathrm{a}$ & $20.9 \mathrm{a}$ \\
200 & $63.3 \mathrm{a}$ & $21.2 \mathrm{a}$ & $25.8 \mathrm{a}$ & $20.4 \mathrm{a}$ \\
400 & $57.9 \mathrm{~b}$ & $19.7 \mathrm{~b}$ & $23.5 \mathrm{~b}$ & $18.6 \mathrm{~b}$ \\
Significance & $* * *$ & $* * *$ & $* * *$ & $* *$
\end{tabular}

${ }^{\mathrm{z}}$ Mean separation within columns by LSD at $P \leq 0.05$.

termination times (Fig. 6A). At FT-3, 200 and $400 \mathrm{mg} \cdot \mathrm{L}^{-1} \mathrm{~N}$ caused a delay to reach anthesis.

Phosphorus. The $\mathrm{P}$ rate and fertilizer termination time affected vegetative growth. The $\mathrm{P}$ rate at $25 \mathrm{mg} \cdot \mathrm{L}^{-1}$ caused plants to be taller with more nodes than $0 \mathrm{mg} \cdot \mathrm{L}^{-1}$ (Table $3)$. However, a further increase of $\mathrm{P}$ up to $200 \mathrm{mg} \cdot \mathrm{L}^{-1}$ did not result in any additional increase in node number. Leaf number remaining was largest at $\mathrm{P}$ rates between 25 and $100 \mathrm{mg} \cdot \mathrm{L}^{-1}$, with an average of 19 leaves. Pseudobulbs were widest at $100 \mathrm{mg} \cdot \mathrm{L}^{-1} \mathrm{P}$ and were least at $0 \mathrm{mg} \cdot \mathrm{L}^{-1} \mathrm{P}$. Pseudobulb thickness was similar at 25 to $200 \mathrm{mg} \cdot \mathrm{L}^{-1} \mathrm{P}$, but was thinner at $0 \mathrm{mg} \cdot \mathrm{L}^{-1} \mathrm{P}$ (Table 3 ).

There were effects of fertilizer termination time on plant height, leaves remaining, and pseudobulb width, but the differences were small and not commercially meaningful (data not shown). Pseudobulb thicknesses were similar for FT-1 and FT-2, but were thinner at FT-3 (Fig. 3B).

Total flower number per plant was affected by the $\mathrm{P}$ rate and fertilizer termination time. Plants supplied with 25 to 200 $\mathrm{mg} \cdot \mathrm{L}^{-1} \mathrm{P}$ produced an average of 29 flowers per plant (Figs. 4B and 5B). Plants produced the most flowers (30) when fertilization was ended at FT-2 (Fig. 4B). The least number of apical nonflowering nodes was produced at $0 \mathrm{mg} \cdot \mathrm{L}^{-1} \mathrm{P}$ (three nodes) compared with rates of 25 to $200 \mathrm{mg} \cdot \mathrm{L}^{-1} \mathrm{P}$ (four to five nodes).

Days to anthesis was the only variable showing an interaction between the $P$ rate and fertilizer termination time (Fig. 6B). For all three termination times, plants that were not supplied with $\mathrm{P}$ flowered later than those receiving $P$.

Potassium. For all fertilizer termination times, pseudobulb thickness increased as $\mathrm{K}$ increased from 0 to $200 \mathrm{mg} \cdot \mathrm{L}^{-1}$ and then decreased at $400 \mathrm{mg} \cdot \mathrm{L}^{-1}$ (data not shown). Pseudobulb thickness at any given fertilizer termination time was similar at all $\mathrm{K}$ rates (Fig. 3C).

Plant height and pseudobulb node number increased as the $\mathrm{K}$ rate increased from 0 to $100 \mathrm{mg} \cdot \mathrm{L}^{-1}$, but remained similar from 100 to $400 \mathrm{mg} \cdot \mathrm{L}^{-1} \mathrm{~K}$ (Table 4 ). As the $\mathrm{K}$ rate increased from 0 to $200 \mathrm{mg} \cdot \mathrm{L}^{-1}$, leaves remaining increased but did not increase further at $400 \mathrm{mg} \cdot \mathrm{L}^{-1}$. When supplied with 0 or $50 \mathrm{mg} \cdot \mathrm{L}^{-1} \mathrm{~K}$, there was severe leaf loss, and only $34 \%$ and $62 \%$, respectively, of the leaves remained on plants. Plants supplied with $100 \mathrm{mg} \cdot \mathrm{L}^{-1}$ or higher $\mathrm{K}$ had $72 \%$ to $80 \%$ leaf retention. Pseudobulb width was similar
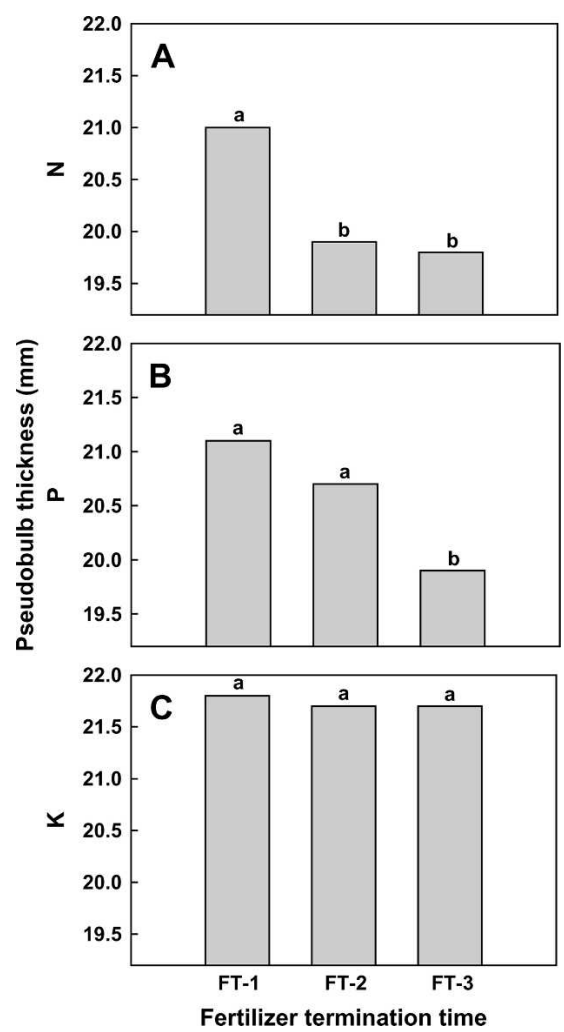

Fig. 3. Effect of nitrogen (A), phosphorus (B), and potassium $(\mathbf{C})$ termination time on pseudobulb thickness measured at time of pseudobulb maturity for Dendrobium cv Red Emperor 'Prince'.
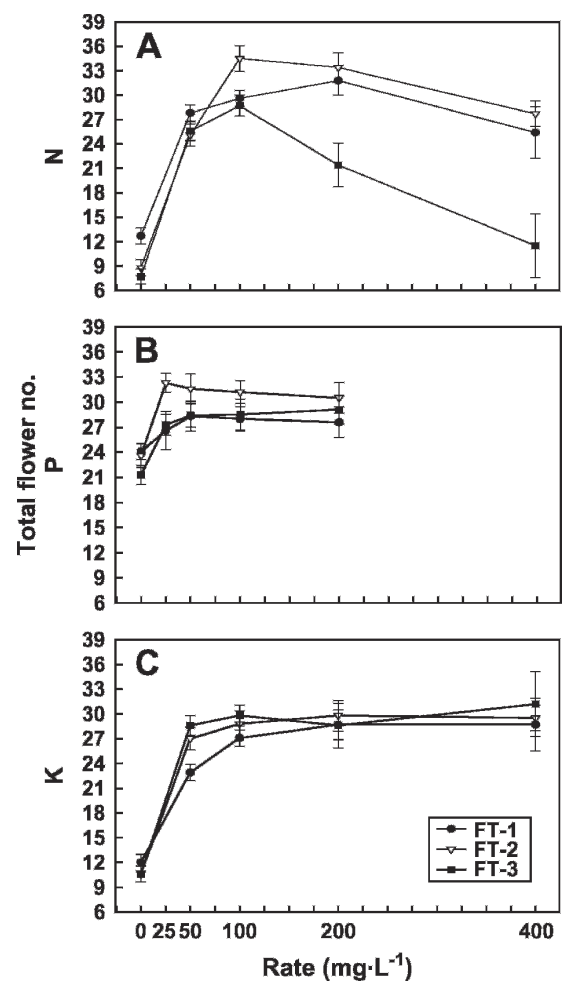

Fig. 4. Effect of the nitrogen (A), phosphorus (B), and potassium $(\mathbf{C})$ rate and fertilizer termination time on total flower number measured at time of full flower for Dendrobium cv Red Emperor 'Prince'. FT-1 = 1 Sept. 2005, FT-2 = 1 Oct. 2005 , FT-3 = 1 Nov. 2005. Bars indicate \pm SE of the mean.

HortScience Vol. 43(2) April 2008 

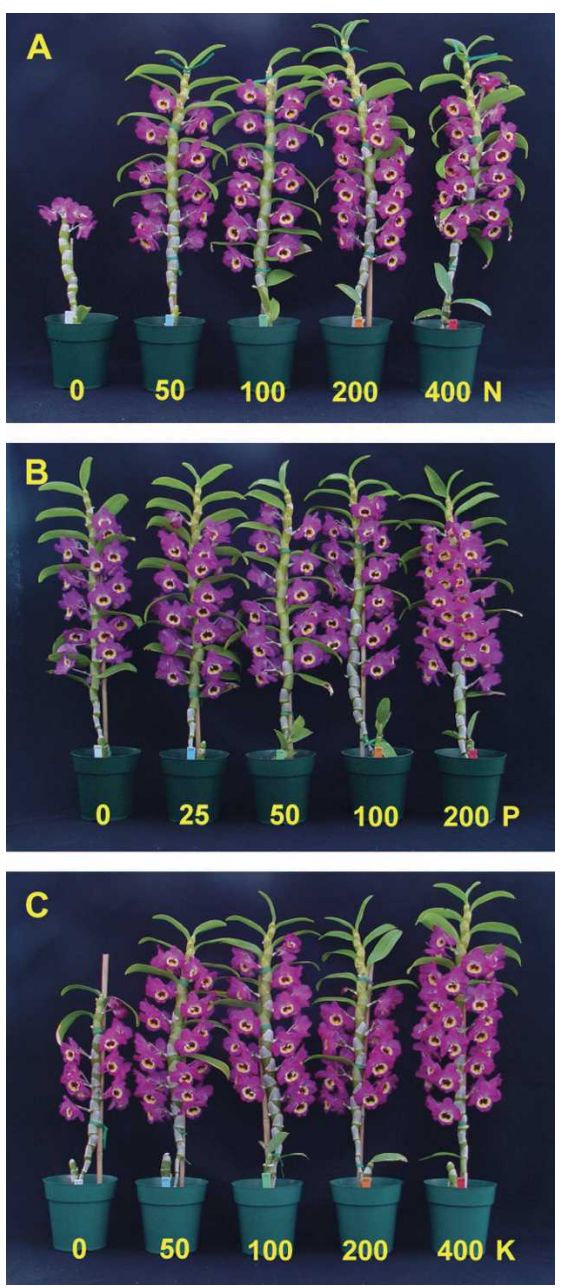

Fig. 5. Effects of the nitrogen (A), phosphorus (B), and potassium $(\mathbf{C})$ rates (in $\mathrm{mg} \cdot \mathrm{L}^{-1}$ ) on flowering for Dendrobium cv Red Emperor 'Prince'.

and greater at rates above $0 \mathrm{mg} \cdot \mathrm{L}^{-1}$, while thickness was greater at 0 , similar and intermediate at 50 to 200 , and thinner at 400 $\mathrm{mg} \cdot \mathrm{L}^{-1} \mathrm{~K}$ (Table 4).

Total flower number (Figs. 4C and 5C) was the lowest at $0 \mathrm{mg} \cdot \mathrm{L}^{-1} \mathrm{~K}$, but remained similar from 50 to $400 \mathrm{mg} \cdot \mathrm{L}^{-1} \mathrm{~K}$. When supplied with 0 or $50 \mathrm{mg} \cdot \mathrm{L}^{-1} \mathrm{~K}$, plants took the fewest number of days to reach anthesis, whereas 1 to $3 \mathrm{~d}$ more were needed for all other $\mathrm{K}$ rates (Fig. 6C).

Extended $N$ application. In this experiment, the duration of $\mathrm{N}$ application did not affect vegetative or flowering characteristics. Plants in all treatments averaged $57.1 \mathrm{~cm}$ in height and had 20 nodes and 17 leaves on pseudobulbs. Pseudobulb width and thickness was 28.6 and $22.1 \mathrm{~mm}$, respectively. There was an average of 28 flowers per plant, and flower diameter averaged $6.6 \mathrm{~cm}$. On average, plants required $388 \mathrm{~d}$ to reach anthesis. There were no aerial shoots formed on plants in this experiment.

\section{Discussion}

Cultivar Red Emperor 'Prince' and other $D$. nobile hybrids have the potential for increased production and to become a popu-
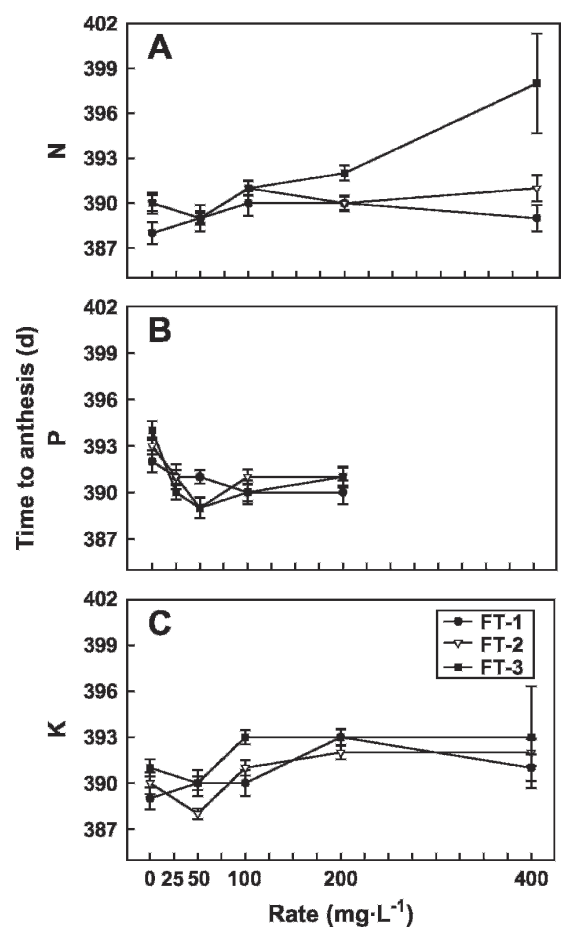

Fig. 6. Effect of the nitrogen (A), phosphorus (B), and potassium $(\mathbf{C})$ rate and fertilizer termination time on days to anthesis measured at time of full flower for Dendrobium cv Red Emperor 'Prince'. FT-1 = 1 Sept. 2005, FT-2 = 1 Oct. 2005 , FT-3 = 1 Nov. 2005. Bars indicate \pm SE of the mean.

lar orchid sold on the mass market. They have long-lasting flowers that come in many colors that appeal to the customer. They have several attributes, including the ability to closely space them in the greenhouse, that give them a high value per unit of bench area. Applying optimum amounts of nutrients for the correct length of time can help commercial producers increase the quality of this orchid and grow it more efficiently.

Nitrogen. Today, consumers prefer that leaves remain on nobile dendrobium potted plants when in full flower. This study showed that no or inadequate $\mathrm{N}$ application caused severe leaf loss (Fig. 2), giving plants a less appealing appearance. One of the typical signs of $\mathrm{N}$ deficiency in plants is the abscission of older leaves (Marschner, 1995).

A leaf, and potentially flowers, can be produced at every node. Node number is an indication of how many flowers may be produced (Rotor, 1952). Plants were taller and had more nodes when they were supplied

Table 3. Effect of the P rate regardless of fertilizer termination time on vegetative parameters measured at pseudobulb maturity for Dendrobium cv Red Emperor 'Prince'.

\begin{tabular}{|c|c|c|c|c|c|}
\hline \multirow[b]{2}{*}{$\mathrm{P}$ rate $\left(\mathrm{mg} \cdot \mathrm{L}^{-1}\right)$} & \multirow{2}{*}{$\begin{array}{c}\text { Plant } \\
\text { height }(\mathrm{cm})\end{array}$} & \multirow{2}{*}{$\begin{array}{c}\text { Pseudobulb } \\
\text { node (no.) }\end{array}$} & \multirow{2}{*}{$\begin{array}{c}\text { Leaf } \\
\text { remaining (no.) }\end{array}$} & \multicolumn{2}{|c|}{ Pseudobulb } \\
\hline & & & & Width (mm) & Thickness (mm) \\
\hline 0 & $55.3 \mathrm{c}^{\mathrm{z}}$ & $18.4 \mathrm{~b}$ & $16.8 \mathrm{~b}$ & $24.2 \mathrm{c}$ & $19.4 \mathrm{~b}$ \\
\hline 25 & $60.1 \mathrm{~b}$ & $19.8 \mathrm{a}$ & $18.4 \mathrm{a}$ & $24.7 \mathrm{bc}$ & $20.5 \mathrm{a}$ \\
\hline 50 & $62.3 \mathrm{ab}$ & $20.2 \mathrm{a}$ & $19.0 \mathrm{a}$ & $26.0 \mathrm{ab}$ & $21.1 \mathrm{a}$ \\
\hline 100 & $63.6 \mathrm{a}$ & $20.8 \mathrm{a}$ & $19.2 \mathrm{a}$ & $26.7 \mathrm{a}$ & $20.9 \mathrm{a}$ \\
\hline 200 & $62.6 \mathrm{a}$ & $20.6 \mathrm{a}$ & $17.1 \mathrm{~b}$ & $25.9 \mathrm{ab}$ & $20.8 \mathrm{a}$ \\
\hline Significance & $* * *$ & $* * *$ & $* * *$ & $* *$ & $* * *$ \\
\hline
\end{tabular}

${ }^{\mathrm{z}}$ Mean separation within columns by LSD at $P \leq 0.05$. with 100 or $200 \mathrm{mg} \cdot \mathrm{L}^{-1} \mathrm{~N}$ compared with lower and higher rates. Wang (1996) used rates of 100 and $200 \mathrm{mg} \cdot \mathrm{L}^{-1} \mathrm{~N}$ of each of six $\mathrm{N}, \mathrm{P}$, and $\mathrm{K}$, as well as different sources of $\mathrm{N}$, and reported that Phalaenopsis grown in a medium of $70 \%$ fine grade fir bark and 30\% peat produced larger leaves that were wider when $\mathrm{N}$ was applied at the higher rate. In this study, similar numbers of leaves were produced when plants were supplied with 100 to $400 \mathrm{mg} \cdot \mathrm{L}^{-1} \mathrm{~N}$ at all three fertilizer termination times. Because these plants were taller and had a greater pseudobulb node number, they also produced more flowers, except for those receiving 200 or $400 \mathrm{mg} \cdot \mathrm{L}^{-1} \mathrm{~N}$ until FT-3.

Pseudobulbs of the nobile dendrobium swell and become thicker only after the top leaf has unfolded and shoot elongation has ceased. Because FT-1 plants had thicker pseudobulbs, they may have matured earlier. When plants were fertilized until FT-2 or FT3 , they might not have matured as early, and were thinner and narrower. When pseudobulbs mature earlier, they can be forced to produce flowers and sold at earlier market dates.

Excess $\mathrm{N}$ application has been considered a common cause of poor flowering (Yamamoto Dendrobiums, 2006). Again, this is probably because of the prolonged vegetative state and delayed pseudobulb maturation as a result of prolonged fertilizer application. Flowering characteristics were similar for FT-1 and FT-2 termination times. Therefore, to reduce fertilizer inputs and assure flowering, fertilizer could be ended at the FT-1 with similar results.

From the results of this experiment, 100 $\mathrm{mg} \cdot \mathrm{L}^{-1} \mathrm{~N}$ is recommended for Dendrobium cv Red Emperor 'Prince'. This rate provides the amount of nutrients the plant can use efficiently for excellent vegetative growth and reproductive development with the least fertilizer input. Application of $100 \mathrm{mg} \cdot \mathrm{L}^{-1} \mathrm{~N}$ to plants resulted in similar or greater plant height, pseudobulb width and thickness, as well as similar flowering characteristics compared with plants receiving higher rates. This is comparable to Poole and Seeley's (1978) findings for Phalaenopsis and Cymbidium grown in nutrient culture. Of the rates they used $\left(50,100\right.$, and $\left.200 \mathrm{mg} \cdot \mathrm{L}^{-1} \mathrm{~N}\right), 100 \mathrm{mg} \cdot \mathrm{L}^{-1}$ $\mathrm{N}$ was recommended because it resulted in greater leaf and root dry weights and larger leaves, and it increased plant height. However, each species of orchid has a different $\mathrm{N}$ fertilizers containing varying percentages of 
Table 4. Effect of the $\mathrm{K}$ rate regardless of fertilizer termination time on vegetative parameters measured at pseudobulb maturity for Dendrobium cv Red Emperor 'Prince'.

\begin{tabular}{cccccc}
\hline $\begin{array}{l}\text { K rate } \\
\left(\mathrm{mg} \cdot \mathrm{L}^{-1}\right)\end{array}$ & $\begin{array}{c}\text { Plant } \\
\text { height }(\mathrm{cm})\end{array}$ & $\begin{array}{c}\text { Pseudobulb } \\
\text { node no. }\end{array}$ & $\begin{array}{c}\text { Leaf } \\
\text { remaining }(\text { no. })\end{array}$ & Width $(\mathrm{mm})$ & Thickness $(\mathrm{mm})$ \\
\hline 0 & $41.0 \mathrm{c}^{\mathrm{z}}$ & $14.6 \mathrm{c}$ & $4.8 \mathrm{~d}$ & $23.0 \mathrm{~b}$ & $27.4 \mathrm{a}$ \\
50 & $54.6 \mathrm{~b}$ & $18.3 \mathrm{~b}$ & $11.8 \mathrm{c}$ & $27.1 \mathrm{a}$ & $21.7 \mathrm{~b}$ \\
100 & $59.0 \mathrm{a}$ & $20.1 \mathrm{a}$ & $14.4 \mathrm{~b}$ & $27.6 \mathrm{a}$ & $21.4 \mathrm{~b}$ \\
200 & $60.2 \mathrm{a}$ & $20.5 \mathrm{a}$ & $16.2 \mathrm{a}$ & $27.7 \mathrm{a}$ & $21.3 \mathrm{~b}$ \\
400 & $59.1 \mathrm{a}$ & $20.0 \mathrm{a}$ & $16.3 \mathrm{a}$ & $27.8 \mathrm{a}$ & $19.0 \mathrm{c}$ \\
Significance & $* * *$ & $* * *$ & $* * *$ & $* * *$ & $* * *$ \\
\hline
\end{tabular}

${ }^{\mathrm{z}}$ Mean separation within columns by LSD at $P \leq 0.05$.

requirement for optimal growth in different media. Poole and Seeley (1978) also reported that Cattleya grown under the same conditions and rates had larger leaves and greater dry weights of leaves and roots when supplied with $50 \mathrm{mg} \cdot \mathrm{L}^{-1} \mathrm{~N}$. These are much lower optimal $\mathrm{N}$ rates than the optimal $1000 \mathrm{mg} \cdot \mathrm{L}^{-1}$ N observed by Miwa and Ozaki (1975).

Phosphorus. Of the three macronutrients tested, $\mathrm{P}$ is not required in high concentrations (above $25 \mathrm{mg} \cdot \mathrm{L}^{-1}$ ) by Dendrobium cv Red Emperor 'Prince'. Plants receiving $\mathrm{P}$ at rates greater than $0 \mathrm{mg} \cdot \mathrm{L}^{-1}$ had similar vegetative characteristics such as plant height, pseudobulb node number, and pseudobulb thickness. Plant height, node number, and leaf number remaining were greater at the FT-2 fertilizer termination time. When fertilizer was ended at FT-3, pseudobulbs were thinner, possibly indicating that the prolonged vegetative growth resulted in the pseudobulb not maturing like plants whose fertilizer was ended at an earlier time. Our results confirmed the findings of Miwa and Ozaki (1975) that flowering was delayed when no P was applied.

Plants had two more nodes once $\mathrm{P}$ was applied, regardless of the rate. However, application of $\mathrm{P}$ increased total flower count, indicating that $\mathrm{P}$ is needed for initiating more flower primordia. The number of apical nonflowering nodes increased as P rate increased, which may be considered a negative effect on the appearance of a plant in full flower. These results suggest that the $\mathrm{P}$ requirement for Dendrobium cv Red Emperor 'Prince' is low for reproductive development. Each plant produced over 20 flowers, even when no $\mathrm{P}$ was applied.

Wang (2000) found that for Phalaenopsis grown in a mix consisting of Douglas Fir bark and sphagnum peat, $50 \mathrm{mg} \cdot \mathrm{L}^{-1} \mathrm{P}$ was adequate for good vegetative growth and reproductive development. Similar to these findings, the P rate recommended for Dendrobium cv Red Emperor 'Prince' based on this experiment would be $25 \mathrm{mg} \cdot \mathrm{L}^{-1}$ ended at FT-2 for the best vegetative growth and reproductive development.

Potassium. Potassium is the other macronutrient that is needed at higher rates for optimal vegetative growth of Dendrobium cv Red Emperor 'Prince'. Plants were taller and had higher pseudobulb node numbers with the application of $100 \mathrm{mg} \cdot \mathrm{L}^{-1} \mathrm{~K}$ or higher.
Applying adequate levels of $\mathrm{K}$ increased leaf retention. When supplied with 0 or 50 $\mathrm{mg} \cdot \mathrm{L}^{-1} \mathrm{~K}$, there was severe leaf loss, suggesting that $\mathrm{K}$ greater than $50 \mathrm{mg} \cdot \mathrm{L}^{-1}$ is necessary for adequate leaf retention. Bhattacharjee (1981) reported that there were beneficial effects on pseudobulbs of $D$. moschatum cv 'Wall' grown in hard wood charcoal when supplied with $500 \mathrm{mg} \cdot \mathrm{L}^{-1} \mathrm{~K}$, but no further benefits resulted from the application of 1000 $\mathrm{mg} \cdot \mathrm{L}^{-1} \mathrm{~K}$. Both 500 and $1000 \mathrm{mg} \cdot \mathrm{L}^{-1} \mathrm{~K}$ levels resulted in plants that had more leaves than plants receiving $0 \mathrm{mg} \cdot \mathrm{L}^{-1} \mathrm{~K}$ (Bhattacharjee, 1981). In contrast, Poole and Seeley (1978) reported Cymbidium plants had fewer leaves when supplied with $200 \mathrm{mg} \cdot \mathrm{L}^{-1} \mathrm{~K}$ than plants receiving 50 or $100 \mathrm{mg} \cdot \mathrm{L}^{-1}$. They also determined that the $\mathrm{K}$ levels tested had no effect on growth of Phalaenopsis, Cattleya, and Cymbidium and therefore concluded that 50 $\mathrm{mg} \cdot \mathrm{L}^{-1} \mathrm{~K}$ was sufficient.

Potassium fertilizer termination time had no effect on vegetative characteristics. Fertilizer termination at FT-2 resulted in similar or increased reproductive characteristics and therefore is recommended.

Vegetative and reproductive characteristics were similar or greater at $100 \mathrm{mg} \cdot \mathrm{L}^{-1} \mathrm{~K}$, with the exception of greater leaf number remaining and pseudobulb thickness, and larger flowers when plants were supplied 200 $\mathrm{mg} \cdot \mathrm{L}^{-1} \mathrm{~K}$. Therefore, $100 \mathrm{mg} \cdot \mathrm{L}^{-1} \mathrm{~K}$ is the recommended rate to produce quality plants and minimize the amount of fertilizer input. On the contrary, Miwa and Ozaki (1975) reported $\mathrm{K}$ to have no effect on flowering.

Extended $N$ application. There was comparatively no difference among the $\mathrm{N}$ termination times in this experiment. Both vegetative growth and reproductive development measurements were very similar to those recorded in the $\mathrm{N}$ experiment. Because $\mathrm{NH}_{4} \mathrm{NO}_{3}$ was used to provide $\mathrm{N}$, the molar concentration of $\mathrm{NO}_{3}^{-}$and $\mathrm{NH}_{4}{ }^{+}$in the fertilizer solution was equal. The ratio of $\mathrm{NO}_{3}-\mathrm{N}$ and $\mathrm{NH}_{4}-\mathrm{N}$ can affect plant growth, and a mixed supply of $\mathrm{NO}_{3}-\mathrm{N}$ and $\mathrm{NH}_{4}-\mathrm{N}$ usually results in good plant growth (Marschner, 1995). Control plants that continued to receive $\mathrm{N}$ and other nutrients until full flower were similar to plants whose $\mathrm{N}$ was ended at earlier times but continued to receive all other nutrients. When nutrient application in Phalaenopsis was ended at four different dates (1 Sept., 29 Sept., 27 Oct., or 24 Nov.) or was continuously fed, there was no difference in flower diameter; however, continuously fed plants produced more flowers than plants whose fertilizer was ended on the three earlier dates (Wang, 2000).

The average height of the plant was shorter, but overall vegetative characteristics were similar for plants in the $\mathrm{N}$ experiment that received $100 \mathrm{mg} \cdot \mathrm{L}^{-1} \mathrm{~N}$ and those in the extended $\mathrm{N}$ application experiment. Differences between the two experiments were that in the $\mathrm{N}$ experiment, when all fertilizer was ended at FT-2, a greater number of flowers were produced. Times needed to reach anthesis were similar among the control plants and the termination times of the extended $\mathrm{N}$ application experiment. They were also similar to those plants supplied $100 \mathrm{mg} \cdot \mathrm{L}^{-1} \mathrm{~N}$ in the $\mathrm{N}$ experiment at all termination times. Therefore, eliminating $\mathrm{N}$ only at each termination time had similar effects as eliminating all fertilizer at each of the termination times except for flower number, which reinforces that $\mathrm{N}$ should be ended early for best flowering.

\section{Literature Cited}

Baker, M.L. and C.O. Baker. 1996. Orchid species culture. Timber Press, Portland, OR.

Bhattacharjee, S.K. 1981. The effects of nitrogen, phosphorus, and potassium on growth and flowering of Dendrobium moschatum Wall. Gartenbauwissenschaft 46:178-181.

Britt, J. 2000. The status of commercial production of potted orchid around the world. HortTechnology 10:435-436.

Marschner, H. 1995. Mineral nutrition of higher plants. 2nd ed. Academic Press, Boston, MA.

Miwa, S. and H. Ozaki. 1975. Fertilization of Dendrobium nobile grown in bark. I. The effects of nitrogen, phosphorus and potassium on plants potted in sphagnum moss and hemlock bark. Shizuoka Agr. Expt. Sta. Bull. 20.

Poole, H.A. and J.G. Seeley. 1978. Nitrogen, potassium and magnesium nutrition of three orchid genera. J. Amer. Soc. Hort. Sci. 103: 485-488.

Rotor, G.B., Jr. 1952. Daylength and temperature in relation to growth and flowering of orchids. Cornell Univ. Agr. Expt. Sta. Bull. 885.

U.S. Department of Agriculture. 2006. Floriculture crops 2005 summary. Special Crops 6-1(06). 10 June 2006. <http://www.usda.gov/nass>.

Wang, Y.T. 1996. Effects of six fertilizers on vegetative growth and flowering of Phalaenopsis orchids. Scientia Hort. 65:191-197.

Wang, Y.T. 1998. Impact of salinity and media on growth and flowering of a hybrid Phalaenopsis orchid. HortScience 33:247-250.

Wang, Y.T. 2000. Impact of a high phosphorus fertilizer and timing of termination of fertilization on flowering of a hybrid moth orchid. HortScience 35:60-62.

Wang, Y.T. and E.A. Konow. 2002. Fertilizer source and medium composition affect vegetative growth and mineral nutrition of a hybrid moth orchid. J. Amer. Soc. Hort. Sci. 127:442-447.

Yamamoto Dendrobiums. 2006. Yamamoto Dendrobiums, Hawaii. 20 Feb. 2005. <www. yamamotodendrobiums.com>. 